\title{
PROFITABILITY OF THE ITALIAN CREDIT COOPERATIVE BANKS
}

\section{Ossola, Giovanni; Giovando, Guido; Crovini, Chiara}

School of Management, University of Turin, Turin, Italy

\begin{abstract}
Our research explores the Italian banking sector. It's focus on the world of Credit Cooperative Banks (BCCs). The reality of the mutual banks in Italy is very important: they are 364 BCCs in 2015 for a total of over 4,400 branches throughout the Italian territory. The employees are over 37,000 .
\end{abstract}

This study can help us understand the context and the main business in which banks operate. Data were extracted from Bankscope, which is a database containing comprehensive information on financial companies (banks and insurance companies) in Italy. Our sample represents 264 Italian BCCs.

In our research we want to show that the BCCs are relevant in the Italian banking sector and then the sample data are particularly significant also as an indicator of the Italian banking sector, then we have appropriately calculated the two indicators: the Profit Margin and ROE, and we put them in comparison to see how they have changed over the years.

At the end we calculate the Pearson correlation ratio between Profit/Loss and Net Banking Income of each year. Thanks to this relationship, we are able to analyze the possible correlation of Net Banking Income on the profitability of the banks, in order to assess the effects of a policy that is carried out by governance to face the difficulties that the banking world is going through.

Keywords: credit cooperative banks, Profit/loss, Net banking Income, Roe

\section{INTRODUCTION}

The banking system of the Credit Cooperative in Italy finds its origins in the last quarter of 1800. Since their inception these credit cooperative phenomena were closely linked to the local communities in which they were establish, in fact thanks to the deep knowledge and mutual members of the community, their family situation, their personal reputation were singled out to creditworthy people. 
The earliest forms of cooperative credit in Italy were the rurals and artisans who, inspired by Christian values, played a key role in stimulating the humble groups of rural people, especially farmers and craftsmen to obtain loans on terms more favourable than those applied to traditional banks.

Since then, Rural and Artisan banks have maintained a very close relationship with the territory of reference, weaving their own story with that of the communities, as to be "local banks call".

The rural banks were also called upon to fulfil a social function, as well as financial income. In other words, the aim was not to maximize profits, but rather support the local economy. Their role was, in fact, to carry out lending activities against people belonging to certain occupational groups such as farmers and artisans, themselves members of the cooperative bank, within a given territory in order to promote social and economic development of community.

The rural banks were able to grow in number and spread over time, supporting the socio-economic development of their local areas.

In 1993, the Banking Act lays down a radical change since the naming ranging from "Rural and Artisan banks "to the current "mutual banks". By means of this decree are not operating limitations of BCCs that can offer so all the products and services of other banks.

The system of mutual banks in Italy today includes 364 banks for a total of over 4,400 branches throughout the Italian territory. The employees of the banks are over 37,000.

In total there are more than one million and two hundred thousand members of the mutual banks and mutual banks are more than 6 million customers.

The remainder of this study is organized as follows. In Paragraph 1, we provide the Literature Review. In Paragraph 2 we define the methodology. In Paragraph 3 we show the findings of our study. Discussions are presented in Paragraph 4 and conclusions in the last part of the research.

\section{LITERATURE REVIEW}

The structure and functioning of the banking company has been studied in its entirety by many scholars (Koch and MacDonald, 2007; Ossola, 2005; Giovando and Gianoglio, 1999; Giovando, 1996). Many scholars have studied the bank account (Bocchino et al., 2013; Ossola, 2005), its performance (Barros et al., 2007; Berger and Allen, 2005; Boubakri et al., 2005) and its financial analysis (Hartvigsen, 1992). Recent studies concentrated on the accounting policy of banks, focusing on the application of the International Accounting Standards (Dezzani et al., 2014) and other specific studies focused on the analysis of the assets and liabilities of the balance sheets (Ossola, 2000).

Innovation, Entrepreneurship and Digital Ecosystems

ISBN: 978-9963-711-43-7 
In addition other researchers have recently analysed the impact of the new capital requirements under Basel III on bank lending rates and loan growth (Khalert and Wagner, 2015). As a result higher capital requirements, raising the marginal cost of bank funding, have led to higher rates (Cosimano, et al., 2011; Elliott, 2009; Laeven and Valencia, 2008).

Some studies focused on the way some financial entities have addressed this moment of global crisis (Crowley, 2015; Costa and Thegeia, 2013; Avdjie et al. 2012; Caprio et al., 2011). Many researchers concentrated on this period of financial crisis (Kapan and Minoiu, 2015; Calvo, 2012), highlighting the crucial role played by the liquidity risk in the stability of a bank, and, more generally, in the financial system (Borio, 2008; Dell'Ariccia et al., 2008). Some have tried to locate the perimeter within which identify the financial risk and study methods for good management, in accordance with the requirements of Basel (Álvarez and Rossignolo 2015; Angelini, et al. 2011).

An important study analyses, by means of alternative techniques, both cost and profit efficiency in a sample of ten countries of the European Union for the period 1993-1996, again obtaining profit efficiency levels lower than cost efficiency levels (Maudos, 2002).

For many years, a comparison of accounting ratios in the banking sector has shown the existence of remarkable differences in average costs. Wide ranges of return on equity (ROE) are found, although these results are more difficult to evaluate due to their greater instability.

Other studies have focused on these issues in particular the effect of banks' capitalization on banks' Return on Equity (ROE) (Blaga, 2015). A debate has emerged on the costs for banks of the increase in capital requirements under Basel III (Camara, 2014).

Some researchers analysed the performance of banks belonging to individual countries (Faisal et al., 2015; Raus and Fu, 2014; Iqbal and Raza, 2009; Ali and Ansari, 2007; Barros Ferreira and Williams, 2007).

Iannotta, Nocera and Sironi (2007) as well as Illueca, Norden and Udell (2008) documented that bank ownership is an important determinant of lending behaviour, risk taking and performance.

With reference to the Italian context the importance of local small banks, such as BCCs, was emphasized in few studies (Usai and Vannini, 2005; Ferri and Messori, 2000), several researchers concentrated on this kind of banks, in terms of characteristics and role within the Italian banking sector (Bonfante, 2010; Agostini, 2009; Costa, 2007; Capriglione 2005; Bonfante, 2004; Vella, 2004; Appio, 1996). Zago and Dongili (2014) examined in depth the impact of the financial crisis on the Italian credit 
cooperative banks and the technical efficiency of the Italian BCCs for the period 2003 to 2012. They also discussed and tested different specifications and objective functions for BCCs.

The importance of local small banks, such as BCCs, was emphasized in few studies.

Our research fits into this theme by analyzing the banking world of Italian BCCs. We considered, a sample of 264 Italian BCCs banks, which represent more than $72 \%$ of the all Italian BCC. In addition, we covers the period between 2009 and 2014. Moreover, we did not implement a sophisticated statistical model in order to pursue the effectiveness of the results and to concentrate on the real relationship between the items considered. However, thanks to our analysis, we tried to find a relation between net assets and net banking income and profit/loss of the banks of the sample.

Our approach is balance-sheet and income statement based, consequently we started from the data extracted from Bankscope database and consequently from the financial statements of banks. However, despite the limits of the research, thanks to this analysis and the results obtained, we may consider the opportunities of growth and development of our analysis.

In conclusion, one of the aims of this research is to improve the existing literature by using an empirical approach.

\section{METHODOLOGY}

The following paragraphs describe the sample and the methodology followed to conduct our research.

\subsection{The sample and the data}

This analysis focuses on the Italian BCCs banks. Our sample represents 264 Italian BCCs total of 364 BCCs on the Italian territory, between period 2009- 2014. We decided to exclude the banks of which had not for all the years considered its financial statements. To homogenize the sample analyzed by the totality of the BCCs were excluded those that did not had the balance sheet data of a few years taken into consideration.

This study can help us understand the context and the main business in which banks operate. Data were extracted from Bankscope, which is a database containing comprehensive information on financial companies (banks and insurance companies) in Italy. In the first part of Phase 2, we focused on information about Net Assets, Net banking Income and Profit/Loss.

We want to specify that data provided in our figures all refer to the mean of the single element analysed. 
In the second part, we concentrated on some ratios, such as Profit/Loss on Equity to total Assets and Net Banking Income on Profit/Loss on, provided by Bankscope.

\subsection{Research questions and phases of analysis}

The present research is based on the following hypotheses:

- H1: The BCCs represent a significant banking institution in the Italian territory;

- H2: The Net banking Income is the profitability linked to the core business of banking. In the sample of BCCs examined the Net banking Income is preponderant.

To reach the goals of this study, we need to formulate three research questions:

- RQ1: What is the trend during the period monitored between the Net banking Income and the Profit/loss?

- RQ2: What is the trend in the period between 2009 and 2014 between the Profit Margin and ROE ?

- RQ3: Is there a correlation between the Net banking Income and the Profit/loss ?

The research methodology follows three phases:

a) Phase 1: Analysis of the BCCs world and its characteristic features.

b) Phase 2: Empirical analysis and findings. It involves an analysis of the information derived from the sample. The research methodology only uses the information provided in the financial statements because it is sufficient to answer the research questions.

With reference to $R Q 1$, we want to show that the BCCs are relevant in the Italian banking sector and then the sample data are particularly significant also as an indicator of the Italian banking sector.

Referring to RQ2, we have appropriately calculated the two indicators: the Profit Margin and ROE, and we put them in comparison to see how they have changed over the years.

We concentrated on the analysis of the Profit Margin Ratio and ROE because we based our research on the Dupont analysis. It also called the Dupont model and it is a financial ratio based on the return on equity ratio that is used to analyze a company's ability to increase its return on equity. In other words, this model breaks down the return on equity ratio to explain how companies can increase their return for investors.

The Dupont analysis looks at three main components of the ROE ratio: 
- $\quad$ Profit Margin;

- $\quad$ Total Asset Turnover;

- $\quad$ Financial Leverage.

Based on these three performances measures the model concludes that a company can raise its ROE by maintaining a high profit margin, increasing asset turnover, or leveraging assets more effectively. The Dupont Corporation developed this analysis in the 1920s. The name has stuck with it ever since.

With reference to $R Q 3$, we calculate the Pearson correlation ratio between Profit/Loss and Net Banking Income of each year. Thanks to this relationship, we are able to analyze the possible correlation of Net Banking Income on the profitability of the banks, in order to assess the effects of a policy that is carried out by governance to face the difficulties that the banking world is going through.

As mentioned above, the correlation ratio of Pearson (p) is used to identify a positive or negative correlation between the Profit / Loss and Net Banking Income. For this, it is necessary to emphasize the following conditions:

- if $\mathrm{p}>0$ there is a direct correlation;

- if $p=0$ there is no correlation;

- if $\mathrm{p}<0$ there is a indirect correlation;

- if $0<\mathrm{p}<0.3$ the correlation is weak;

- if $0.3<p<0.7$ the correlation is moderate;

- if $\mathrm{p}>0.7$ the correlation is strong.

c) Phase 3: Conclusions and limitations of the research.

\section{FINDINGS}

First of all, before analysing the data obtained, we want to give further details and definitions.

The Profit Margin Ratio is an index that is created as the ratio of Profit/loss and Net banking Income. This index shows the impact of different management from the Net banking Income on the operating result. ROE (Return on Equity) is calculated as the ratio between net income and shareholders' equity. It represents the net return for the shareholder. 
Phase 1 concerns the stages of our research and the related comments.

Starting with HP1, BCC is a structured system on a network of approximately 364 Cooperative Banks. The main feature of the BCC is to be widely spread in our country, for over 130 years played their role of local banks, performing a specific function, to promote development and to address the economic and social needs of local communities. On Italian territory have 4,414 branches $14.8 \%$ of the Italian bank branches, with 1,248,724 members and 36,500 employees (including those of the Company's system). The total funding (deposits from banks + customer deposits + bonds) amounted to EUR 196.7 billion and a Customer deposits + bonds: 161.8 billion euro.

The market share of customer deposits including bonds is 7.7\%. Economic Loans totaled 134 billion euro. The market share of lending for mutual banks is $7.2 \%$.

Including loans granted by banks of the second level of the Cooperative Credit, loans amounted to 149 billion euro, for a $8 \%$ market share. On the basis of the data and the considerations it can be argued that HP1 is confirmed and BCCs are important banking institutions in Italy. In order to proceed in our analysis we present in Table 1 the data collected referred to our sample in the period 2009-2014.

\begin{tabular}{|c|c|c|c|c|c|c|c|}
\hline \multirow[t]{2}{*}{ Table 1} & & \multicolumn{6}{|c|}{ Main items considered in the financial statement analysis } \\
\hline & & 2009 & 2010 & 2011 & 2012 & 2013 & 2014 \\
\hline \multirow{5}{*}{$\begin{array}{l}\text { Net } \\
\text { Assets }\end{array}$} & Mean & $€ 53.248 .775$ & $€ 54.146 .355$ & $€ 51.875 .244$ & $€ 58.385 .757$ & $€ 59.852 .789$ & $€ 62.900 .690$ \\
\hline & Median & $€ 38.887 .792$ & $€ 37.894 .855$ & $€ 36.578 .651$ & $€ 42.534 .866$ & $€ 42.651 .894$ & $€ 44.934 .293$ \\
\hline & Max & 574.282 .677 & 581.983 .976 & $€ 563.434 .911$ & $€ 644.165 .552$ & $€ 706.866 .923$ & $€ 747.322 .795$ \\
\hline & Min & $€ 2.806 .597$ & $€ 2.310 .158$ & $€ 2.102 .883$ & $€ 3.071 .128$ & $€ 2.608 .013$ & $€ 1.234 .285$ \\
\hline & $\begin{array}{l}\text { Std. } \\
\text { Dev. }\end{array}$ & $€ 58.023 .361$ & $€ 59.627 .273$ & $€ 58.253 .290$ & $€ 64.450 .364$ & $€ 67.170 .376$ & $€ 71.058 .513$ \\
\hline \multirow{5}{*}{$\begin{array}{l}\text { Net } \\
\text { banking } \\
\text { Income }\end{array}$} & Mean & $€ 15.271 .042$ & $€ 14.654 .857$ & $€ 15.829 .806$ & $€ 18.808 .016$ & $€ 19.202 .108$ & $€ 22.360 .217$ \\
\hline & Median & $€ 11.032 .347$ & $€ 10.384 .311$ & $€ 11.501 .707$ & $€ 13.211 .618$ & $€ 14.155 .574$ & $€ 16.069 .505$ \\
\hline & Max & $€ 219.821 .974$ & $€ 96.943 .712$ & $€ 190.368 .842$ & $€ 250.573 .032$ & $€ 217.946 .906$ & $€ 248.110 .914$ \\
\hline & Min & $€ 302.681$ & $€ 902.261$ & $€ 1.148 .809$ & $€ 1.248 .021$ & $€ 1.353 .727$ & $€ 1.715 .234$ \\
\hline & $\begin{array}{l}\text { Std. } \\
\text { Dev. }\end{array}$ & $€ 18.024 .387$ & $€ 16.826 .969$ & $€ 17.151 .888$ & $€ 21.322 .259$ & $€ 21.372 .301$ & $€ 25.148 .830$ \\
\hline \multirow{5}{*}{$\begin{array}{l}\text { Profit/ } \\
\text { Loss }\end{array}$} & Mean & $€ 2.159 .771$ & $€ 1.370 .879$ & $€ 1.323 .646$ & $€ 1.428 .378$ & $€ 512.429$ & $€ 1.203 .610$ \\
\hline & Median & $€ 1.302 .454$ & $€ 894.464$ & $€ 916.636$ & $€ 1.115 .313$ & $€ 767.636$ & $€ 917.666$ \\
\hline & Max & $€ 33.638 .627$ & $€ 30.257 .871$ & $€ 18.106 .653$ & $€ 20.144 .982$ & $€ 21.140 .332$ & $€ 25.913 .278$ \\
\hline & Min & $-€ 3.511 .339$ & $€ 13.770 .862$ & $-€ 14.483 .137$ & $-€ 23.517 .128$ & $-€ 25.747 .756$ & $-€ 13.979 .750$ \\
\hline & $\begin{array}{l}\text { Std. } \\
\text { Dev. }\end{array}$ & $€ 3.202 .692$ & $€ 3.309 .409$ & $€ 2.536 .456,97$ & $€ 3.437 .043$ & $€ 3.979 .242$ & $€ 3.795 .589$ \\
\hline
\end{tabular}




\begin{tabular}{|l|l|l|l|l|l|l|l|}
\hline \multirow{2}{*}{$\begin{array}{l}\text { Profit } \\
\text { Margin }\end{array}$} & Mean & $13,98 \%$ & $7,18 \%$ & $8,83 \%$ & $8,61 \%$ & $0,67 \%$ & $5,23 \%$ \\
\cline { 2 - 7 } & Median & $13,58 \%$ & $9,48 \%$ & $9,20 \%$ & $9,49 \%$ & $2,17 \%$ & $6,23 \%$ \\
\cline { 2 - 7 } & Max & $191,02 \%$ & $40,95 \%$ & $38,56 \%$ & $44,74 \%$ & $12,32 \%$ & $42,04 \%$ \\
\cline { 2 - 8 } & Min & $-52,64 \%$ & $-87,98 \%$ & $-63,03 \%$ & $-93,18 \%$ & $-36,10 \%$ & $-110,23 \%$ \\
\cline { 2 - 8 } & $\begin{array}{l}\text { Std. } \\
\text { Rev. }\end{array}$ & $14,70 \%$ & $15,74 \%$ & $10,79 \%$ & $14,70 \%$ & $6,62 \%$ & $16,42 \%$ \\
\cline { 2 - 8 } & Mean & $3,96 \%$ & $2,00 \%$ & $2,76 \%$ & $2,57 \%$ & $0,67 \%$ & $1,60 \%$ \\
\cline { 2 - 8 } & Median & $3,90 \%$ & $2,69 \%$ & $2,92 \%$ & $3,10 \%$ & $2,17 \%$ & $2,32 \%$ \\
\cline { 2 - 7 } & Max & $13,38 \%$ & $14,56 \%$ & $14,25 \%$ & $16,93 \%$ & $12,32 \%$ & $27,51 \%$ \\
\cline { 2 - 7 } & Mtd. & $-11,64 \%$ & $-36,91 \%$ & $-19,77 \%$ & $-76,27 \%$ & $-36,10 \%$ & $-52,20 \%$ \\
\hline
\end{tabular}

Table 1. Main Items considered in the financial statement analysis

With reference to RQ 1, Figure 1 shows the trend of Net Banking Income and Profit Loss in the period between 2009 and 2014. The data refer to the mean of the sample for each year.

By analysing Table 1, we can affirm that HP2 cannot be confirmed in all the years considered.

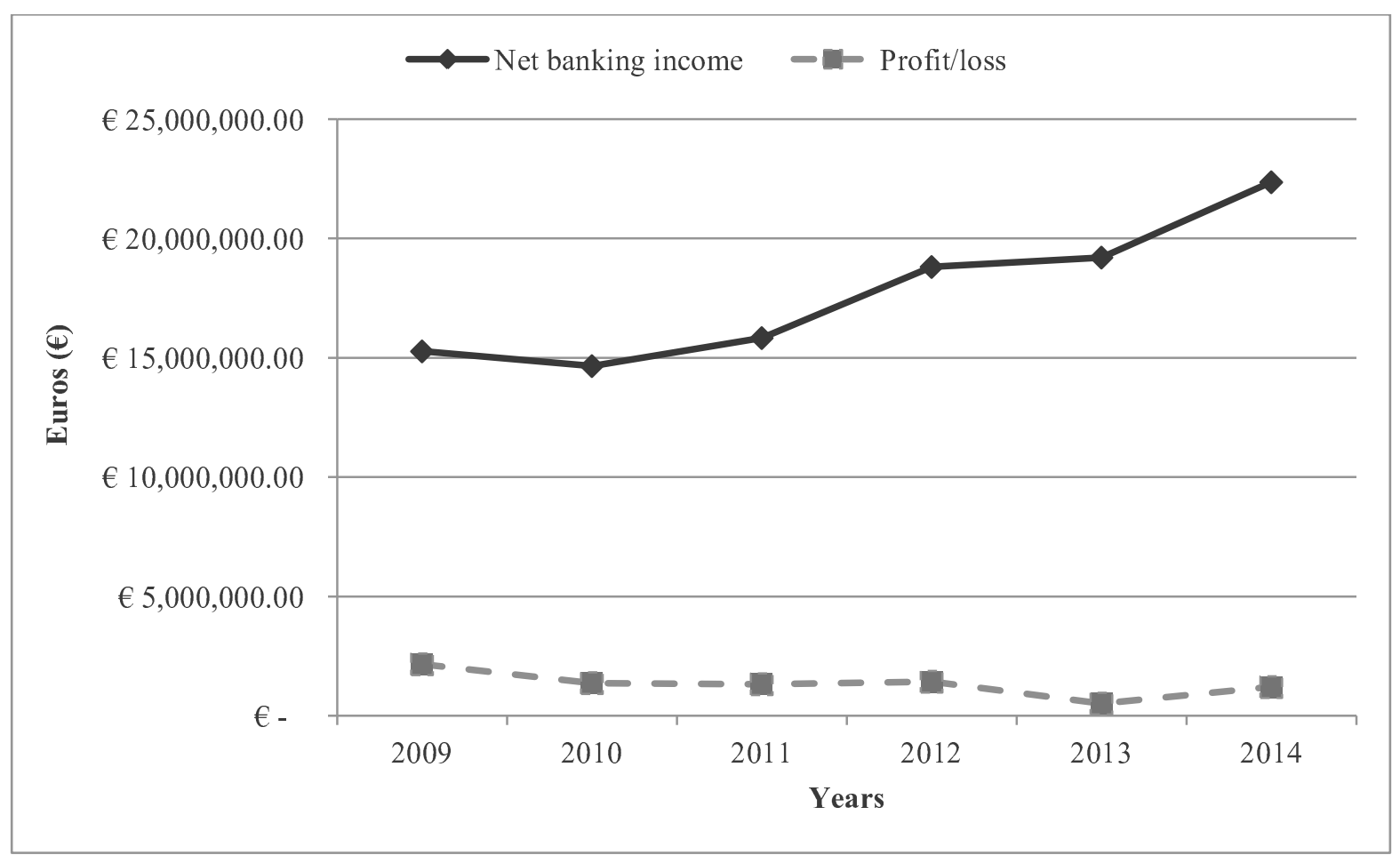

Figure 1. The trend of Net Banking Income and Profit/Loss of BCCs in the period between 2009 and 2014

The figure confirms our first hypothesis. Therefore, in the sample of banking firms considered, it can be noted that the Net Banking Income substantially in the years follow the Profit / Loss. 
Continuing our analysis in order to answer RQ2, we analyze the second figure.

The Profit Margin Ratio is an index that is created as the ratio of Profit/loss and Net banking Income, instead, ROE (Return on Equity) is calculated as the ratio between net income and shareholders' equity.

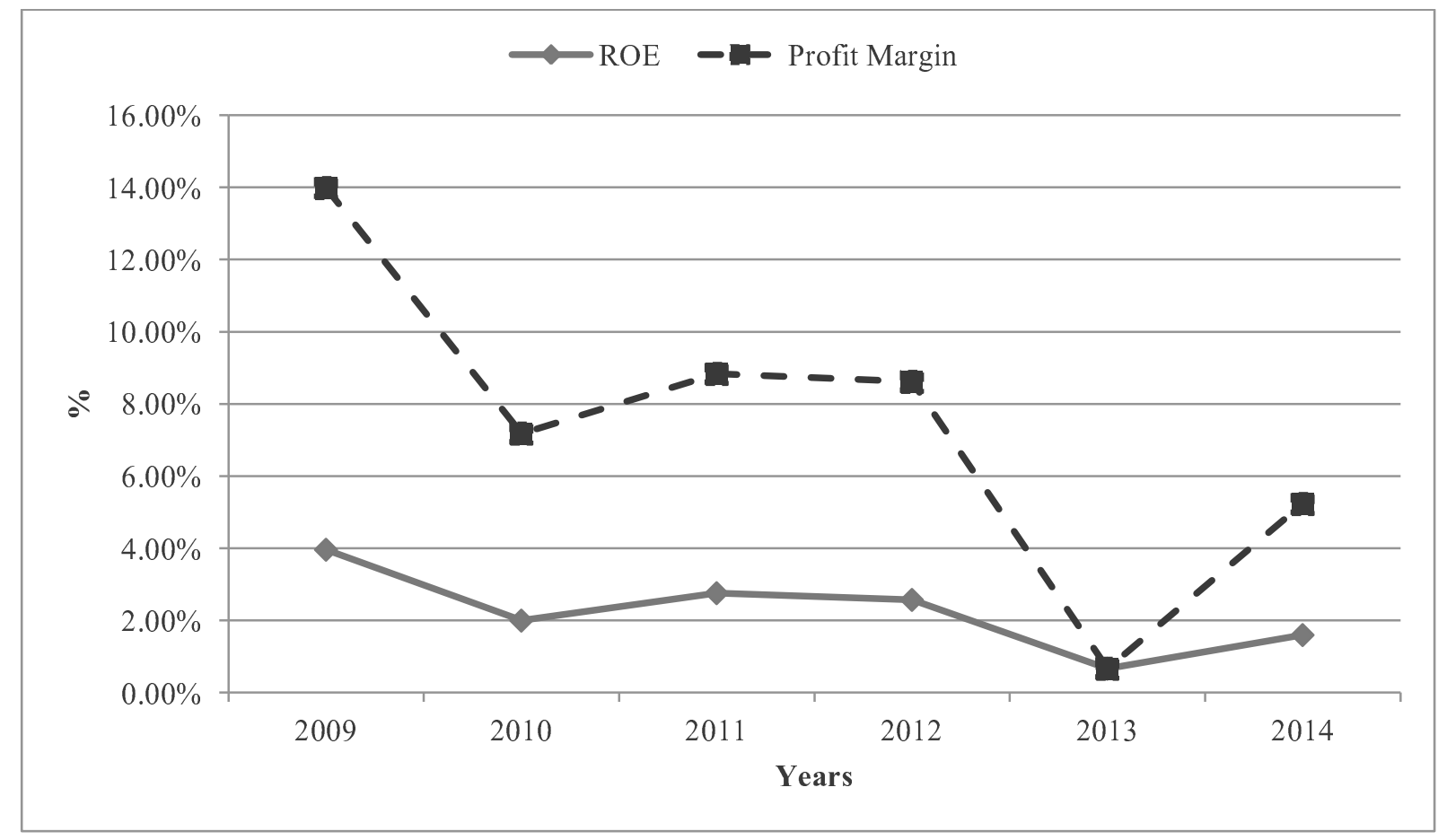

Figure 2. The trend of ROE and the Profit Margin Ratio of BCCs in the period between 2009 and 2014

In this figure it can be noted how the two indices do not comply with the same deviations. This shows that in the sample analyzed ROE is almost stable over the years analyzed but its composition is different.

The two figures demonstrate that the initial first hypothesis is true. In fact, as can be seen from 2009 to 2012 the Profit Margin is at higher levels of ROE while in 2013 the Profit Margin goes down is the same level of ROE and then climbs slightly up in 2014.

In order to answer RQ3, we calculated the Pearson correlation ratio between Profit/Loss and Net Banking Income of each year between 2009 to 2014.

Table 2 shows the results deriving from the Pearson correlation ratio calculated. 


\begin{tabular}{|c|c|c|c|c|c|c|c|c|}
\hline Table 2 & \multicolumn{8}{|c|}{ The Pearson correlation ratio between Profit/loss and Net banking income } \\
\hline & \multirow{8}{*}{$\begin{array}{l}\text { Net } \\
\text { Banking } \\
\text { Income }\end{array}$} & \multicolumn{7}{|c|}{ Profit/Loss } \\
\hline & & & 2009 & 2010 & 2011 & 2012 & 2013 & 2014 \\
\hline & & 2009 & 0.87 & & & & & \\
\hline & & 2010 & & 0.70 & & & & \\
\hline & & 2011 & & & 0.56 & & & \\
\hline & & 2012 & & & & 0.48 & & \\
\hline & & 2013 & & & & & 0.29 & \\
\hline & & 2014 & & & & & & 0.55 \\
\hline
\end{tabular}

Table 2. The Pearson correlation ratio between Profit/Loss and Net Banking income

The current table confirms that there is a strong correlation between the Profit / Loss and the Net Banking Income in 2009 and 2010. Instead, the correlation started decreasing from 2011 to 2013. In fact in 2013, the Pearson ratio is 0.29. In 2014, the ratio recovered.

Therefore, we can affirm that RQ3 can't be confirmed for all the years considered. And especially in recent years it is not confirmed.

In more recent years the correlation is very low.

\section{DISCUSSIONS}

Our research and its results confirm what many previous studies stated before: the mutual banking system in Italy is important. In the world of Italian banking group BCCs are definitely relevant. Our HP1 was confirmed by the analysis of data and numbers of the whole Italian BCC system giving ample confirmation initial hypothesis.

As mentioned above, the system of mutual banks in Italy today includes 364 banks for a total of over 4,400 branches throughout the Italian territory, $14.8 \%$ of the Italian bank branches. The employees of the banks are over 37,000. Italian BCC system have 1,248,724 members and 36,500 employees (including those of the Company's system). The total funding (deposits from banks + customer deposits + bonds) amounted to EUR 196.7 billion and a Customer deposits + bonds: 161.8 billion euro. 
The market share of customer deposits including bonds is 7.7\%. Economic Loans totaled 134 billion euro. The market share of lending for mutual banks is $7.2 \%$. Including loans granted by banks of the second level of the Cooperative Credit, loans amounted to 149 billion euro, for a $8 \%$ market share.

As regards HP2 and RQ1 we can affirm that the Net Banking Income trend was positive.

But the value of the Net Banking Income between 2009-2011 was not as significant, while the Profit Loss trend declined significantly between 2009 and 2010 and remained constant until 2012 and then, again, decrease in 2013. In 2014, instead the Profit, it returned to grow.

Surely the financial and economic crisis has had a negative effect both on the Net Banking Income is the profit. The decrease in 2013, the profit is linked to a negative impact of the extra-ordinary management.

As regards RQ2 the answer is less convincing. From the analysis we have carried on our sample indicates that if in the early years (2009 and 2010) there is a substantial correlation is not the case in recent years.

So we can argue that in the years 2009 and 2010, the Profit / Loss was influenced by the Net Banking Income. In the following years this correlation is lower, in fact, in 2013 the Pearson index is around 0.29 .

This may mean that in the following years the crisis and the persistence of the banking crisis of the BCCs has diversified its activities. Those activities that affect our income statement therefore do not always represent the core business of banking.

So RQ2 is not verified and we can deduce that the banking business over the years has evolved in areas not always the bank's core. All this can also be explained by the crisis of the banking business and then accordingly also in bank intermediation which led the bank's governance to change their business objectives.

\section{CONCLUSIONS}

This study focused on the world of Italian BCCs. We could analyze their size with a very significant sample. From this study we were able to note the relevance of the BCCs in Italy.

Later we have tested the sample the possible relevance of Net Banking Income on Profit / Loss.

Afterwards we analyzed the Profit Margin Ratio (index that is created as the ratio of Profit/loss and Net banking Income) and ROE (Return on Equity) during the period 2009 to 2014.

Innovation, Entrepreneurship and Digital Ecosystems

ISBN: 978-9963-711-43-7 
Finally we concentrated on the relationship between Net Banking Income and the Profit/Loss of the data Italian BCCs banks between the period 2009 and 2014. We have noticed that the correlation in recent years appears weak.

We noted that such importance was low especially in recent years. The study thus points out that the banking business especially during the crisis years has moved away of the core to explore and develop other activities.

Data were extracted from a database, called Bankscope, which is a database containing comprehensive information on financial companies (banks and insurance companies) in Italy.

Our research raises important questions regarding the BCCs field of the resonance in Italy and the evolution of their business in recent years.

What we have also analyzed possible to introduce all the limitations of this research. First, this study represents the first step of a much deeper analysis that can take into account other variables, financial indicators and margins. We decided not to use an extremely complex model because we aimed to achieve effective results and focusing on the true relationship between the factors taken into account.

One of the future developments is to extend both the years under consideration in the same analysis to other banks that do not belong to the world BCCs in order to compare and contrast the situation between different realities.

\section{REFERENCES}

Agostini S., (2009), Le banche di credito cooperativo, Cooperativa e consorzi, n.10, Ipsoa, Milano

Ali, A. and Ansari, I. A. (2007), Financial sector reforms and soundness of banks operating in Pakistan, Journal of Management and Social Sciences, 3(2),63-69.

Álvarez, V. A., and Rossignolo A.F., (2015), Análisis Comparativo De Técnicas (IMA) Para Determinar Capitales Mínimos Regulados Por Basilea, Ante Crisis En Mercados Emergentes (Comparative Analysis of Techniques (IMA) for Determining Minimum Capital Regulated by Basel, Facing Crises in Emerging Markets, Social Science Research Network. ODEON (8),13-14. Available at SSRN: http: //ssrn.com/abstract = 2566754 .

Angelini, P., L. Clerc, V. Cúrdia, L. Gambacorta, A. Gerali, A. Locarno, R. Motto, W. Roeger, S. Van den Heuvel, and J. Vlček, (2011), Basel III: Long-Term Impact on Economic Performance and Fluctuations, Federal Reserve Bank of New York Staff Report, 485.

Appio, C.L., (1996), Le banche di credito cooperativo tra Testo Unico e disciplina del diritto comune, in Dir. banc. merc. Fin. Avdjie, S., Zsolt K., and Előd T. (2012), The Euro Area Crisis and Cross-Border Bank Lending to Emerging Markets, BIS Quarterly Review.

Barros Ferreira, P.C, and Williams, J. (2007), Analyzing the determinants of performance of best and worst European banks, Journal of Banking and Finance, 31 (7):2189-2203.

Berger, Allen N. ,(2005), Corporate governance and bank performance: A joint analysis of the static, selection, and dynamic effects of domestic, foreign, and state ownership, Journal of Banking \& Finance, 29(8-9):2179-2221.

Blaga, L., (2015) The Influence of the Endogenous and Exogenous Factors on Credit Institutions' Return on Equity - Arad - Economics Series 25(1), 16-25, DOI: 10.1515/sues-2015-0002.

Bocchino, U., Ossola, G., Giovando, G., Venuti, F. (2013), Il bilancio delle banche, Giuffrè, Milano 
Bonfante, G., (2004), Commento all'art. 2538 c.c., in Il nuovo diritto societario. Commentario, diretto da Cottino Bonfante - Cagnasso - Montalenti, Bologna

Bonfante, G.,(2010), La nuova società cooperativa, Zanichelli, Bologna

Borio, C., (2008), The financial turmoil of 2007. A preliminary assessment and some policy considerations, BIS Working Papers No. 251

Calvo, G., (2012), Financial crises and liquidity shocks a bank-run perspective, European Economic Review Volume 56(3), 317-326.

Camara, B.; Castellani F.-D.; Fraisse H.; Frey, L.; Héam C.; Labonne, L.; Martin, V. 2015 Does the capital structure affect banks' profitability? Pre- and post financial crisis evidence from significant banks in France, in Mercure : A Macroprudential Stress Testing Model

Capriglione, F., (2005), Le banche cooperative e il nuovo diritto societario. Problematiche e prospettive, in Banca borsa tit. cred.

Caprio, G.D, Klingebiel, Laeven L., and Noguera G., (2005), Appendix: Banking Crisis Database in Patrick Honohan and Luc Laeven (eds.). Systemic Financial Crises: Containment and Resolution, Cambridge, U.K.: Cambridge University Press.

Cosimano, T. F. and Hakura, D., (2011), Bank Behaviour in Response to Basel III: A Cross-Country Analysis. IMF Working Paper No. 11/119. Available at SSRN: http://ssrn.com/abstract=1860182 orhttp://dx.doi.org/10.2139/ssrn.1860182

Costa Navajas, Thegeya A.M., (2013), Financial Soundness Indicators and Banking Crises. Forthcoming IMF Working Paper WP/13/XX.

Costa, C., (2007), La riforma delle società e le banche cooperative, in Il nuovo diritto delle società: Liber amicorum Gian Franco Campobasso, Torino

Crowley, J. (2015), Central and Commercial Bank Balance Sheet Risk Before, During and After the Global Financial Crisis, International Monetary Funds.

Dell'Ariccia, G., Igan, D., Laeven, L., (2008), Credit booms and lending standards: evidence from the subprime mortgage market, IMF Working Papers, 08/106

Dezzani, F., Biancone, P.P. and Busso, D., (2014), IAS/IFRS, IPSOA, Milano.

Elliott, D. J. (2009), Quantifying the Effects on Lending of Increased Capital Requirements,Brookings Briefing Paper. Washington, D.C.: Brookings Institution.

Faisal, M. T. and Farzand A. J. (2015), Financial Performance Of Banks In Pakistan: A Comparative Analysis Of Public And Private Sectors, V fast Transactions On Education And Social Sciences 6(2): 2309-3951.

Ferri, G. and M. Messori (2000), Bank-firm relationships and allocative efficiency in Northeastern and Central Italy and in the South, Journal of Banking and Finance 24, 1067-1095.

Giovando, G. (1996), La banca in AA.VV., Lezioni di Economia Aziendale, Giuffrè, Milano.

Giovando, G., Gianoglio, G. (1999), Le banche in AA.VV., Euro ed Economia Aziendale, Giuffrè, Milano.

Hartvigsen, G. (1992), Limitations of knowledge-based systems for financial analysis in banking, Expert Systems with Applications, 4(1):19-32.

Iannotta, G., Nocera, G., Sironi, A., (2007), Ownership structure, risk and performance in the European banking industry, Journal of Banking and Finance 31(7), 2127-2149.

Illueca, M., Norden, L., Udell, G., (2008), Liberalization, Corporate Governance, and Savings Banks, EFA 2008 Athens Meetings Paper.

Iqbal, J. and Raza, G. (2009), Building global banks: A comparative analysis of European banks over time, Cambridge, U.K.: Cambridge University Press.

Kahlert D., Wagner N., (2015), Are Eurozone Banks Undercapitalized? A Stress Testing Approach to Financial Stability. A Stress Testing Approach to Financial Stability, Working Paper, Available at SSRN: http://ssrn.com/abstract=2568614 orhttp://dx.doi.org/10.2139/ssrn.2568614

Kapan T., Minoiu C., (2015), Balance Sheet Strength and Bank Lending During the Global Financial Crisis, Available at SSRN: http: //ssrn.com/abstract= 2247185 orhttp: //dx.doi.org / 10.2139/ ssrn.2247185

Koch, T., MacDonald, S. (2007), Bank Management, Marson, Ohio: South-Western Cengage Learning, 7 th ed.

Laeven, L., Valencia, F. (2008), Systemic Banking Crisis: A New Database. IMF Working Paper 8-224. Washington, D.C.: International Monetary Fund.

Maudos, J., Pastor, J. M., Pérez, F., Quesada, J. (2002) Cost and profit efficiency in European banks, Journal of International Financial Markets, Institutions and Money, 12(1), February 2002, 33-58 .

Ossola, G., (2000), I bilanci degli enti finanziari, Giuffrè, Milano

Ossola, G., (2005), Gli schemi del bilancio d'esercizio degli enti creditizi, Giuffrè, Milano.

Rauf, S., Fu, Q., (2014), Integrated Model to measure the Impact of E-Banking Services on Commercial banks' ROE: Empirical Study of Pakistan, Atlantis Press. 
Usai, S. and M. Vannini (2005), Banking structure and regional economic growth: lessons from Italy, Annals of Regional Science 39, 691-714.

Vella, F., (2004), La governance delle società cooperative, in La riforma delle società cooperative, a cura di Borzaga Fici, Trento

Zago, A., Dongili, P., (2014), Financial Crisis, Business Model and the Technical Efficiency of Italian Banche di Credito Cooperativo, Quaderni di ricerca del credito cooperativo, n.4, www.creditocooperativo.com 